\title{
9
}

\section{Educational robotics and computational thinking. A didactic experience of innovation at the university level}

\author{
Pedro Román-Graván \\ proman@us.es \\ Orcid: 0000-0002-1646-9247 \\ University of Seville \\ Carlos Hervás-Gómez \\ hervas@us.es \\ Orcid: 0000-0002-0904-9041 \\ University of Seville
}

\author{
Cristóbal Ballesteros-Regaña \\ cballesteros@us.es \\ Orcid: 0000-0002-9959-6953 \\ University of Seville
}

\begin{abstract}
Educational robotics has thrived in recent years and is now gaining increasing presence in educational centres around the world. Although it has been especially significant in stages of secondary education, numerous introductory experiences have begun to be developed in stages of early childhood and primary education. The experience presented in this chapter aims to initiate a research line of educational innovation that will be focused on the didactic integration of the following types of robots: mBot, Mouse Robot and Makey-Makey board.
\end{abstract}

Keywords: educational robotics, computational thinking, university teaching, didactic experience, innovation

\subsection{Previous considerations about the development of the experience}

The studies by Benitti (2012) and Alimisis (2014) demonstrate how educational robotics has thrived in recent years and is now gaining increasing presence in educational centres around the world. 
Although it has been especially significant in stages of secondary education, numerous introductory experiences have begun to be developed in stages of early childhood and primary education.

In Spain, however, although educational robotics has also started to be incorporated in the classrooms, this is still being regarded as an extracurricular activity, mostly due to the boom that this technology has acquired in current society enhanced, among other factors, by the new economic and technological demands derived from an increasingly skilled labor (Smith, 2016).

The experience presented in this chapter aims to initiate a research line of educational innovation that will be focused on the didactic integration of the different types of robots that are currently in the Spanish market.

The first robot was mBot, from the Chinese manufacturer Makeblock (Figure 1), especially designed for stages of primary and secondary education and baccalaureate.

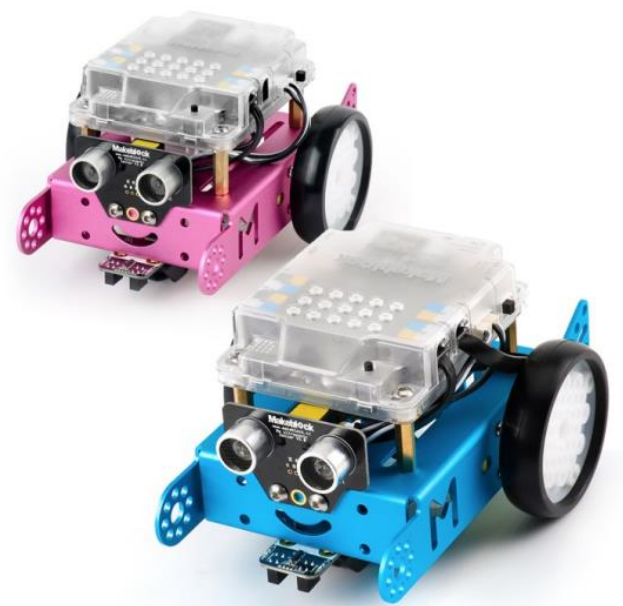

Figure 1. mBot by Makeblock (http://bit.ly/mbot-makeblock)

The second one was Mouse Robot, from the American manufacturer Learning Resources (Figure 2), very similar to the famous Beebot, but more appropriate for early childhood education and the first years of primary education. 


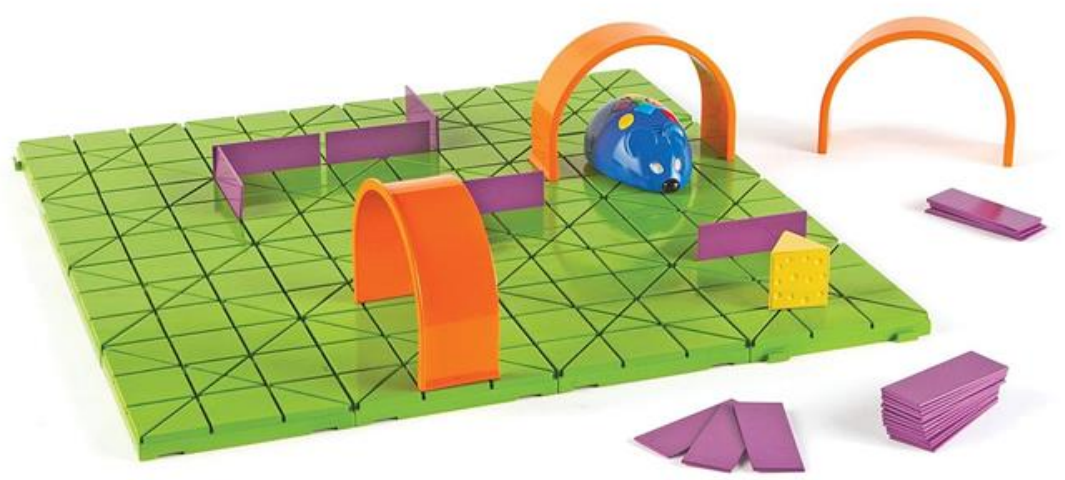

Figure 2. Mouse Robot by Learning Resources (http://bit.ly/mouse-robot)

Lastly, we also worked with the Makey-Makey board, from Joylabz (Figure 3), a young spin-off created by two students of the MIT Media Lab of Massachusetts, U.S.A.

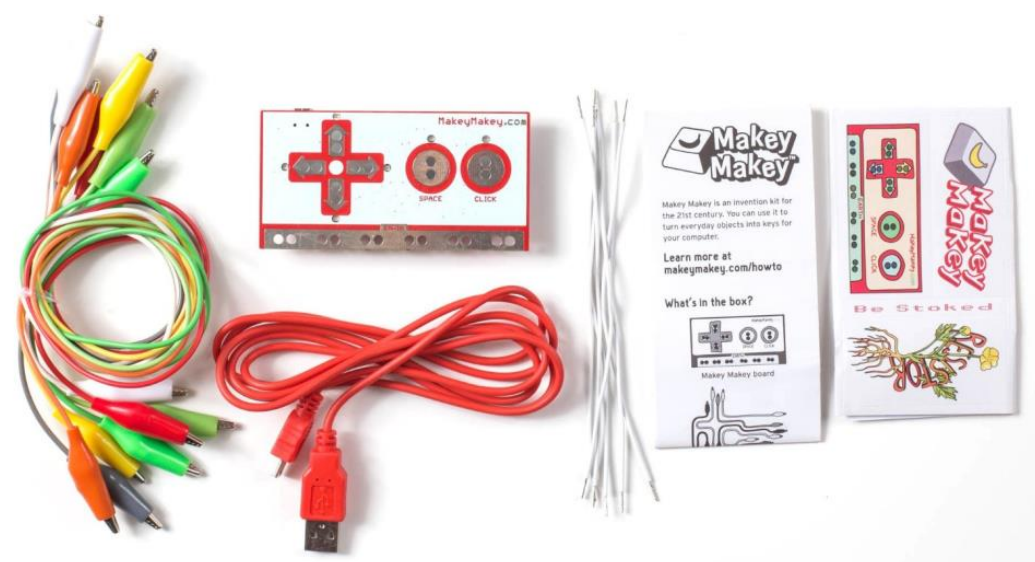

Figure 3. Makey-Makey board by Joylabz (http://bit.ly/placa-makey-makey)

\subsection{Educational robotics and computational thinking: didactic possibilities}

Currently, there is still no generally agreed definition in the scientific community to clarify the concept of educational robotics, pedagogical robotics or didactic robotics. In this sense, Pittí 
(2014) stated that educational robotics is a tool at the service of learning, capable of generating collaborative environments where the participants can practice the skills of the $21^{\text {st }}$ century, which are known as the "4Cs": "Collaboration, Creativity, Communication and Criticism (critical thinking)".

Acuña (2012, p. 8), on the other hand, defines it as a "learning context that promotes a set of performances and skills directly related to the creation, design, construction, programing and dissemination of one's own creations, first mental, then physical, using different technological resources and materials, which can be programmed and controlled from a computer or mobile device".

Therefore, different elements are considered in both cases, such as:

- It is regarded as an interdisciplinary field.

- It requires the creation of a technological object with a specific purpose that is given, depending on the author, different names, such as educational robot, robot prototype and even those who refer to the creation of automatisms, among other considerations.

- It is used in the field of education.

It contributes to the development of key competences and skills for the students of the $21^{\text {st }}$ century.

According to Bravo \& Guzmán (2012) and Román \& Hervás (2017), robotics in the field of education turns out to be a resource that facilitates the learning process and the development of general competences such as socialization, creativity and initiative; these competences will allow students to respond with increasing efficiency and adaptability to the shifting environments that characterize today's society. For these authors, the presence of robotics in the classroom is not exclusively limited to the mere training of students in the field of robotics. On the contrary, they aim to use its multidisciplinary nature to generate learning environments in which students can perceive the problems of the real world and, from them, imagine and formulate the possible solutions, and put them into practice to stimulate their level of involvement and motivation for the subjects they are working on.

Programing and robotics involves Computational Thinking (CT), that is, how machines and computers work, since these are 
programmed by human beings. According to the European Commission (2017), programing is today's literacy and it helps developing new skills such as problem solving, team work or analytical thinking.

Atmatzidou \& Demetriadis (2014) consider CT as a fundamental skill that promotes, among students, new ways of thinking in the different scientific disciplines. Yadav, Mayfield, Zhou, Hambrusch, \& Korb (2014) define CT in a wider way, considering it as a mental activity that allows visualizing problems and formulating automated solutions.

In a society like the one we live in nowadays, increasingly based on information, CT is becoming an essential skill for everyone, as stated, for example, by An \& Lee (2014) through the creation of an initial training course for teachers, whose purpose was the familiarization, understanding and use of CT in the classrooms.

However, despite all the highlighted virtues, the contributions of Alimisis, Moro, Arlegui, Pina, Frangou, \& Papanikolaou (2007) demonstrate how most teachers still refuse to acknowledge the benefits that robotics can bring to the educational processes in the classroom and even, when they do acknowledge so, many of them claim that they are not ready to use and integrate robots didactically in their teaching and learning processes (Mataric, Koenig, \& Feil-Seifer, 2007) and, consequently, to incorporate projects of educational robotics in their classrooms.

Therefore, this multidisciplinary nature of educational robotics requires teachers to acquire knowledge in this field, as well as methodological and didactic strategies, for its curricular integration in the classroom. Thus, according to Alimisis et al. (2007), teachers will have to accompany their students throughout the entire learning process, calculating and adjusting its needs as it develops. This process will require a constant reflection that offers the necessary information to transform the traditional method, directing it toward the promotion of activities that stimulate in students the need for learning through exploration and the search for knowledge and, thus, contribute to the development of their creative thinking and intelligence.

In fact, the study by Sullivan \& Moriarty (2009) demonstrated that some teachers still feel unprepared to carry out teaching activities that involve the use of educational robotics, even after being trained in it. Kim, Choi, Han, \& So (2012) also showed these 
flaws in Korean ICT teachers (considered, a priori, as skilled professionals in this field) and analyzed their training needs, both in programing and educational robotics and in the applicability of these in the classroom. In this regard, Greenberg, McKee, \& Walsh (2013) recommend also as a strategy to limit the number of recruits for the teacher training programs.

According to Fredricks, Blumenfeld, \& Paris (2004), the interest of the teacher leads to an active commitment, in general, whereas uninterested teachers have less chances of making an impact in the classrooms (Kim, Kim, Lee, Spector, \& DeMeester, 2013). Therefore, robotics can be an effective tool in which teachers should become interested and learn about it (through initial and/ or continuing education), at first, and then use it in their teaching processes.

Bers (2008) stated that teacher training in robotics can also produce other positive influences in the teaching practice, such as student-targeted teaching. According to Bravo and Guzmán (2012), educational robotics can keep the attention of students. The fact that students can handle and experiment directly contributes to focus, at all times, their attention, perceptions and observations about the activity being carried out.

Despite the importance of including educational robotics in teacher training (Pittí, Curto, Moreno, \& Rodríguez, 2013), there are still very few studies that focused on this matter. According to Gorman (2016), in order for educational robotics to settle naturally in the classrooms, teachers need more conviction and a lot more training.

Perritt (2010) described professional development using a learning approach based on problems along with robotics. Thus, the more confident the teachers were, the more they used robots and critical thinking in their teaching. Likewise, Osborne, Thomas, \& Forbes (2010) highlighted the importance of teacher training, although they only mentioned the fact that there were workshops for teachers.

Arlegui, Pina, \& Moro (2013) explained more about their teacher training, although they only provided testimonial reports about what the teachers learned and did. Therefore, teachers need to be efficiently trained in order for them to make a proper use of robotics (Bers, 2010:1). 
On the other hand, in the study by Agatolio, Pivetti, Di Battista, Menegatti, \& Moro (2017), the participants showed greater willingness and better attitude toward robotics after receiving a training course. The teachers coincided in the conviction that robotics can improve student motivation to learn. Regarding implementation in the classroom, approximately two thirds of the participants declared that they already had an idea of how they would integrate robotics in the curriculum.

According to Artym, Carbonaro, \& Boechler (2017), computational thinking has been identified by some researchers as a skill desired by students of the 21st century. The challenge for teachers will be to create learning environments that can foster the development of CT in students. Teacher training programs are a unique vehicle to integrate CT skills in their pedagogical practice. It is a clear fact that the growth and creation of employment is linked to the development of innovation in education; thereby, the introduction and training of teachers in basic knowledge of robotics in the present will have a positive impact in the progress of tomorrow's society. However, as stated by Ferreira, Ryan, \& Davis (2015), the institutions that regulate the initial training of teachers are large and complex organizations, and thus, difficult to change.

Lastly, to talk about robotics involves doing so about personal skills and STEM competences, or its STEAM evolution, which is where educational environments are stressing the curriculum and programs of science, technology, engineering and mathematics. In fact, it was because of the narrow approach of STEM (Science, Technology, Engineering and Mathematics) that educators requested a less technical approach that allowed arts, design and humanities to be included (<http://bit.ly/youtube-stem>).

This demand created the space for education in Science, Technology, Engineering, Arts and Mathematics (STEAM), a more transdisciplinary approach focused on problem solving whose primary objective is to prepare students to solve urgent problems of the world through innovation, creativity, critical thinking, efficient communication, collaboration and, lastly, the active generation of new knowledge (Quigley \& Herro, 2016). 


\subsection{A didactic experience of innovation with university students}

The experience of innovation presented in this chapter was carried out during the academic year 2016-2017 in the Faculty of Education Science at the University of Seville, Spain. Two groups of students from the Degree of Early Childhood Education and another two groups from the Degree of Primary Education participated in the experience.

The groups of participants from the Degree of Early Childhood Education were constituted by fourth-year students who undertook the 6-credit basic training subject (<http://bit.ly/tic-infantil-us>): "Information and Communication Technology Applied to Early Childhood Education".

The groups of participants from the Degree of Primary Education were constituted by first-year students that undertook the 6-credit basic training subject (<http://bit.ly/tic-primaria-us>): "Information and Communication Technology Applied to Education".

The experience began with a first session in which we explained to the students the meaning of CT and educational robotics (Figure 4). During this session, they were given a document that contained both the computerized collective presentation used in the session, and different texts that expanded the information presented, which they had to use during the different sessions that covered the entire experimental process.

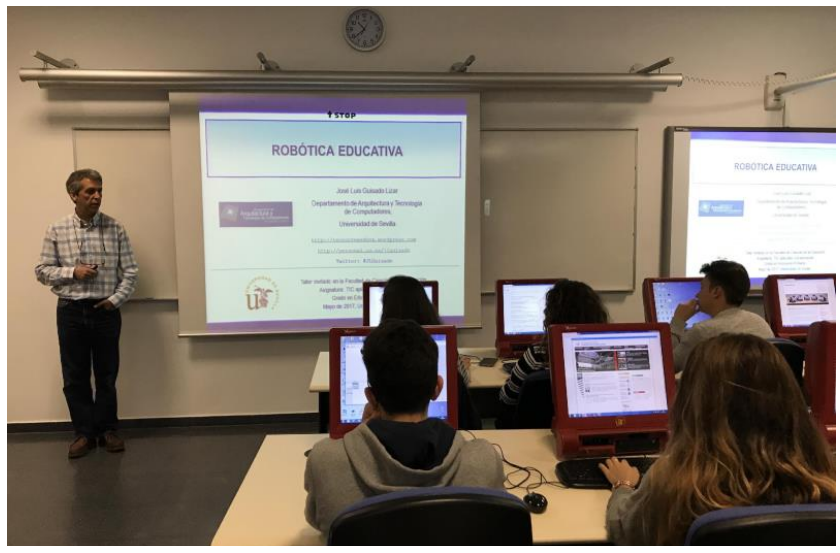

Figure 4. José Luis Guisado, lecturer at the University of Seville, explaining what educational robotics is 
Next, they were introduced to the Scratch and mBlock programing language (the Scratch version to program mBot robots), they proceeded to the assembling of the robots and then they started programing them from the basic notions received (Figure 5).

The practical lecture with mBot consisted in programing the robot in a way that this would move in different directions and even detect obstacles with the ultrasound sensors and avoid them. They also had to make the color LEDs in the top and front of the robot switch on. The following videos (<http://bit.ly/mbot-video $>$ ) show the interaction of the different groups of students with mBot.

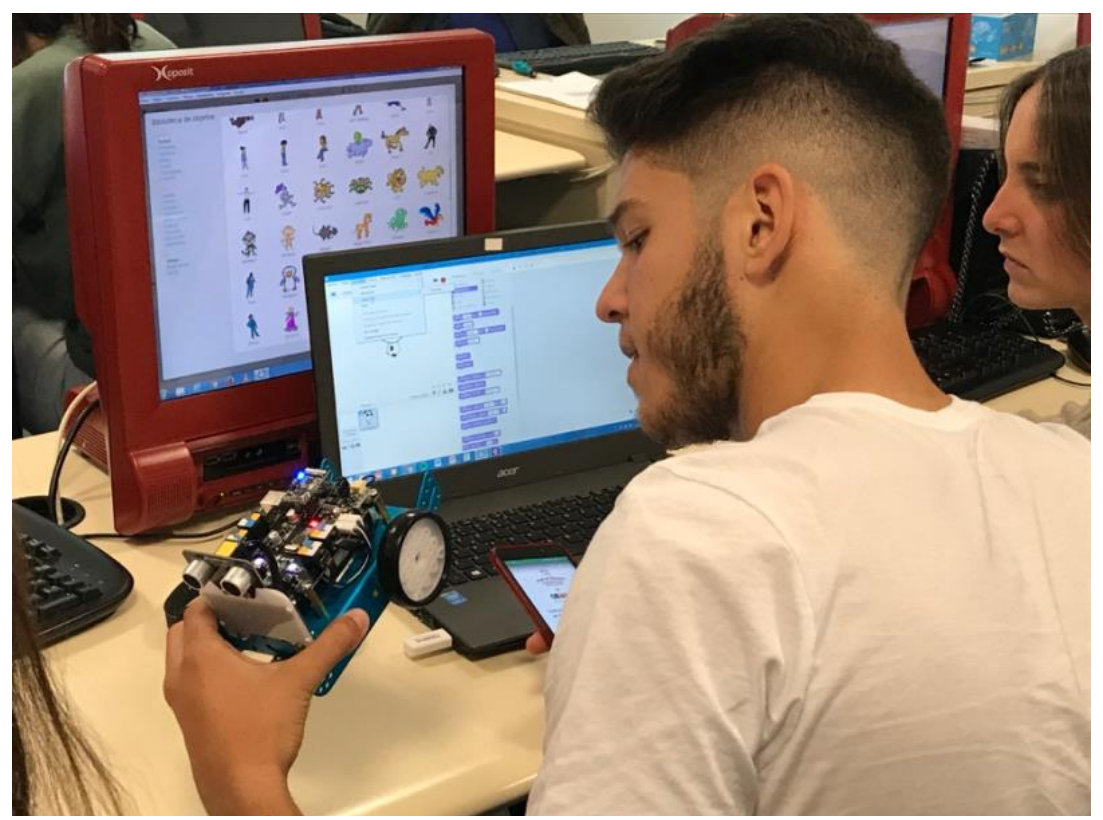

Figure 5. Students programing the $m B$ ot with the $m B l o c k$ programing language

For the learning of Scratch programing language, a simple template was used, which was provided by the non-profit organization "programamos.es" (<https://programamos.es>). Through it, the students programmed a videogame related to healthy eating, in which the famous cat had to stand beneath the fruits falling down the screen and discard the bowls full of sweets (Figure 6).

In the next stage, the students were taught (Figure 7): 
- The functioning and purpose of the second robot: Mouse Robot.

- The procedure to assemble the circuit.

- How to use the orientation chips.

- How to program didactic units with Mouse Robot.

The following video (<http://bit.ly/mouse-robot-video $>$ ) shows all the details about the interaction of the students with Robot Mouse.

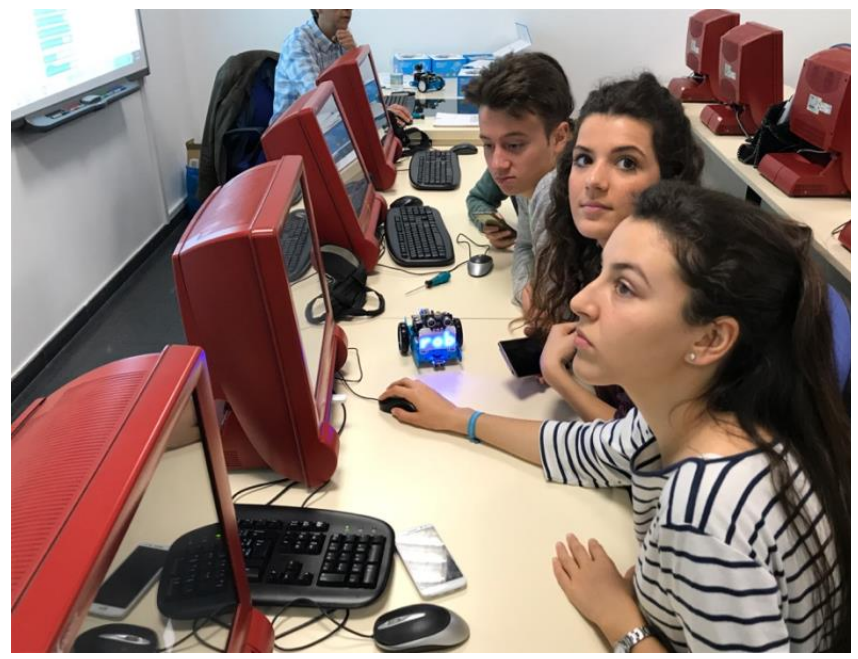

Figure 6. Students programing with the Scratch programing language

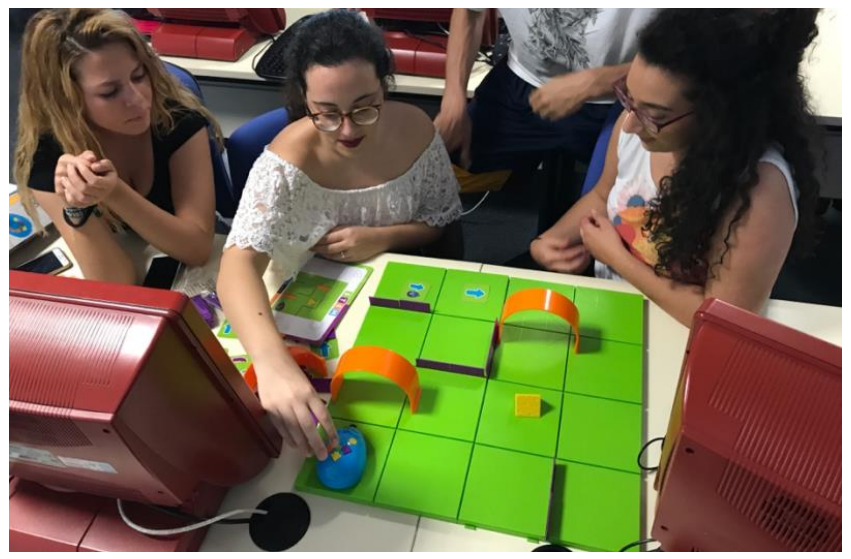

Figure 7. Students interacting with Robot Mouse 
The third and last stage of our experience was designed for the students to learn (Figure 8):

- The functioning of the Makey-Makey board.

- Its different purposes.

- The most suitable methodological and didactic procedure for its curricular integration in the classroom program.

The practical lecture with Makey-Makey consisted in drawing arrows using a pencil (electricity conductors) and programing the board in a way that, when the different arrows touched each other, the computer would reproduce the musical instrument they had assigned: drum, cymbals, etc.
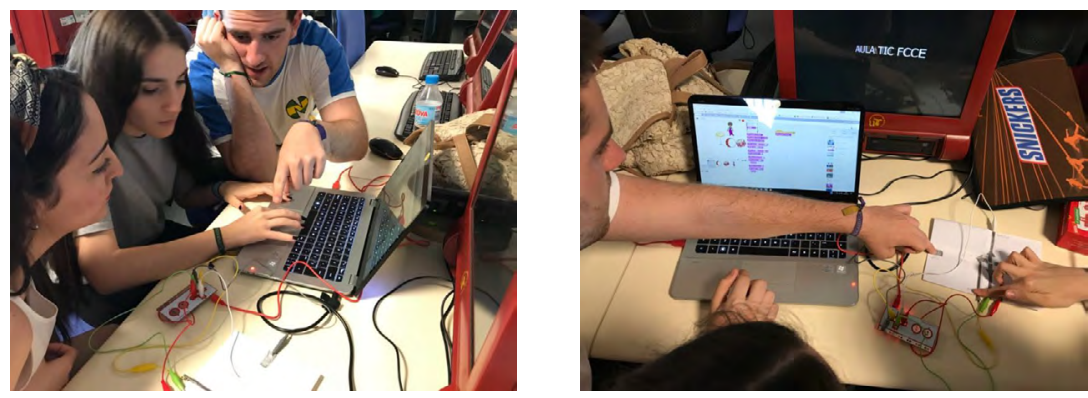

Figure 8. Students programing the Makey-Makey board with Scratch

\subsection{Conclusions}

In order to know in more detail the results obtained from the didactic experience of innovation, with the university students of the Faculty of Education Science at the University of Seville, Spain, we created a satisfaction survey that was administered at the end. From its analysis, the following conclusions were drawn:

a) The general degree of satisfaction shown by the students was very high, since they claimed to be very satisfied with the opportunity that the experience had offered them to interact with the robots and their corresponding applications; they even showed their desire to spend more time doing this kind of activities. Thereby, at this point, we formulate the following 
question: why must teachers have knowledge related to robotics?

b) First of all, because, in the near future, society will require different jobs related to programing and machines. This will be driven by a humanity that will be increasingly computerized, as is already happening in the present, which is also leading many companies to resort to robots for the realization of logistic or marketing activities (assistant robots).

c) The second justification is related to the development of competences (both basic and specific) in the field of education that are acquired or reinforced through programing, among which we can highlight the following: motivation, curiosity, interest, participation, collaborative work, self-learning, critical thinking, shared building of knowledge, access to new means of information and communication, application knowledge, creativity, imagination, learning how to learn, skills in and with ICT, as well as frustration tolerance, among others.

d) Both programing and robotics constitute a booming market driven by the development of new and improved services and products. This is not only happening in sectors like manufacturing, search and rescue, health, housing, transportation and logistics, environment and agriculture, but also in compulsory education, which is where future researchers and scientists will come from.

The transversal nature of robotics is an advantageous aspect to efficiently approach the main concerns that affect us all. Thanks to this characteristic, students can involve in daily matters, such as climate change, sustainable transportation, affordable renewable energies, food safety and even safety itself. Therefore, we must hope that funding for research and innovation will grow exponentially in these areas with the aim of improving the quality of life of all citizens. 


\section{References}

Acuña, A. L. (2012). Diseño y administración de proyectos de robótica educativa: lecciones aprendidas, Revista Teoría de la Educación: Educación y Cultura en la Sociedad de la Información, 13 (3), 6-27. Available at <http://hdl.handle.net/10366/121822>.

Agatolio F., Pivetti M., Di Battista S., Menegatti E., \& Moro M. (2017). A training course in educational robotics for learning support teachers. In Alimisis D., Moro M., \& Menegatti E. (eds), Educational robotics in the makers era. Edurobotics 2016. Advances in Intelligent Systems and Computing (vol. 560). Springer, Cham. doi: <http://doi.org/10.1007/978-3319-55553-9_4>.

Alimisis, D. (2014). Educational robotics in teacher education: an innovative tool for promoting quality education. In Daniela, L., Lūka, I., Rutka, L., \& Žogla, I. (2014), Teacher of the 21st century: quality education for quality teaching. Cambridge scholars publishing, pp. 14-27.

Alimisis, D., Moro, M., Arlegui, J., Pina, A., Frangou, S., \& Papanikolaou, K. (2007). Robostics \& constructivism in education: the TERECoP project. In Proceedings of the 11th European Logo Conference. Comenius University, Bratislava.

An, S. \& Lee, Y. (2014). Development of Pre-service Teacher Education Program for Computational Thinking. In Proceedings of Society for Information Technology \& Teacher Education International.

Arlegui, J., Pina, A., \& Moro, M. (2013). A PBL approach using virtual and real robots (with BYOB and LEGO NXT) to teaching learning key competences and standard curricula in primary level. In Proceedings of the First International Conference on Technological Ecosystem for Enhancing Multiculturality. New York: ACM, pp. 323-328. doi: <http:// doi.org/10.1145/2536536.2536585>.

Artym, C., Carbonaro, M., \& Boechler, P. (2017). Evaluating pre-service teachers' computational thinking skills in scratch. Ubiquitous Learning, 10 (2), 43-65. doi: <https://doi.org/10.18848/1835-9795/CGP/ v10i02/43-65>.

Atmatzidou, S. \& Demetriadis, S. (2014). How to Support Students' Computational Thinking Skills in Educational Robotics Activities. In Proceedings of 4th International Workshop Teaching Robotics, Teaching with Robotics \& 5th International Conference Robotics in Education.

Benitti, F. B. V. (2012). Exploring the educational potential of robotics in schools: A systematic review, Computers \& Education, 58 (3), 978-988. doi: <https://doi.org/10.1016/j.compedu.2011.10.006>. 
Bers, M. U. (2008). Blocks to robots: Learning with technology in the early childhood classroom. New York, NY: Teachers College Press.

- (2010). The Tangible Robotics Program: Applied computational thinking for young children, Early Childhood Research \& Practice, 12 (2). doi: <https://doi.org/10.1007/s10758-017-9328-x>.

Bravo, F. A. \& Guzmán, A. F. (2012). La robótica como un recurso para facilitar el aprendizaje y desarrollo de competencias generales, Teoría de la Educación. Educación y Cultura en la Sociedad de la Información, 13 (2), 120-136. Available at <http://campus.usal.es/ revistas_trabajo/ index.php/revistatesi/article/view/9002/9247>.

European Commission (2017). Digital Single Market. Available at <https:// ec.europa.eu/digital-single-market/en/coding-21st-century-skill>.

Ferreira, J.A., Ryan, L., \& Davis, J. (2015). Developing Knowledge and Leadership in Pre-Service Teacher Education Systems, Australian Journal of Environmental Education. doi: <http://doi.org/10.1017/ aee.2015.24>.

Fredricks, J. A., Blumenfeld, P. C., \& Paris, A. H. (2004). School engagement: potential of the concept, state of the evidence, Review of Educational Research, 74 (1), 59-109. doi: <https://doi. org/10.3102/00346543074001059>.

Gorman, N. (2016). Teachers want more training before introducing robots into the classroom. Available at <http://www.educationworld. com/a_news/teachers-want-more-training-introducing-robots-classroom-1642632440>.

Greenberg, J., McKee, A., \& Walsh, K. (2013). Teacher prep review 2013 report. National Council on Teacher Quality. Available at <http://www. nctq.org/dmsView/Teacher_Prep_Review_2013_Report>.

Kim, C., Kim, M. K., Lee, C., Spector, J. M., \& DeMeester, K. (2013). Teacher beliefs and technology integration, Teaching and Teacher Education, 29, 76-85. doi: <http://doi.org/10.1016/j.tate.2012.08.005>.

Kim, H., Choi, H., Han, J., \& So, H. J. (2012). Enhancing teachers' ICT capacity for the 21st century learning environment: Three cases of teacher education in Korea, Australasian Journal of Educational Technology, 28 (6), 965-982. doi: <https://doi.org/10.14742/ajet.805>.

Mataric, M. J., Koenig, N., \& Feil-Seifer, D. (2007). Materials for enabling hands-on robotics and STEM education. In Proceedings of AAAI Spring Symposium on robots and Robot Venues: Resources for AI Education. Stanford, CA: American Association for Artificial Intelligence (AAAI).

Osborne, R. B., Thomas, A. J., \& Forbes, J. (2010). Teaching with robots: a service-learning approach to mentor training. In Proceedings of the 
41st ACM Technical Symposium on Computer Science Education. New York, NY: Association for Computing Machinery (ACM), pp. 172-176. doi: <https://doi.org/10.1145/1734263.1734321>.

Perritt, D. C. (2010). Including professional practice in professional development while improving middle school teaching in math, National Teacher Education Journal, 3 (3), 73-76.

Pittí, K. (2014). Hoy hablamos con Katia Pittí, experta en robótica educativa, DROIDE, 2014. Available at <http://droidecomunidad.com/ hoy-hablamos-con-kathia-pitti-experta-en-robotica-educativa>.

Pittí, K., Curto, B., Moreno, V., \& Rodríguez, M. J. (2013). Resources and features of robotics learning environments (RLEs) in Spain and Latin America. In Proceedings of the First International Conference on Technological Ecosystem for Enhancing Multiculturality. New York, NY, USA: ACM, pp. 315-322. doi: <http://doi.org/10.1145/2536536.2536584>.

Quigley, C. F. \& Herro, D. (2016). Finding the Joy in the Unknown: Implementation of STEAM Teaching Practices in Middle School Science and Math Classrooms, Journal of Science Education and Technology, 25 (3), 410-426. doi: <https://doi.org/10.1007/s10956-016-9602-z>.

Román, P. \& Hervás, C. (2017). Yes, you can: la robótica en la formación universitaria de maestr@s es posible, Comunicación \& Pedagogía, 301302, 49-52.

Smith, M. (2016). Computer science for all. Available at <https://www. whitehouse.gov/blog/2016/01/30/computer-science-all>.

Sullivan, F. R. \& Moriarty, M. A. (2009). Robotics and discovery learning: Pedagogical beliefs, teacher practice, and technology integration, Journal of Technology and Teacher Education, 17 (1), 109-142. Available at <https://www.learntechlib.org/noaccess/26177>.

Yadav, A., Mayfield, C., Zhou, N., Hambrusch, S., \& Korb, J. T. (2014). Computational thinking in elementary and secondary teacher education, ACM Transactions on Computing Education, 14 (1). doi: <http:// doi.org/10.1145/2576872>. 
